\section{LYELL'S PRINCIPLES OF GEOLOGY}

$\mathrm{T}^{\mathrm{H}}$

$\mathrm{HE}$ appearance of a new edition of the "Principles of Geology "would mark a fitting time to pass in review the state of Geologic Science, to count up what has been added to the treasury of truth, and inquire in what direction and by what methods the pioneers of Science encourage us to search for new facts. Within the limits of a short review, however, it is impossible to do more than call attention to a few of the more striking points which seem to illustrate the principles which we should apply to the examination of the phenomena of the crust of the earth.

We have before us the first edition of the "Principles of Geology," published in 1830 , and that just issued in I 872. It is a remarkable fact that any work on a science which has made such rapid progress as Geology has within the last forty-two years, should, while maintaining the foremost place, have remained so little altered during that period. Almost all the passages which lay down the principles remain word for word as they were originally given to the world; the changes made from time to time being chiefly in the introduction of better illustrations or the consideration of new questions which the progress of research has raised; but to all we find the same methods applied, and from all the same conclusions drawn as to the operation of nature in the production of the visible crust of the earth.

What, then, are the principles laid down? Thoroughly to understand this, we ought to follow our author through the interesting outline he gives of the progress of geological inquiry, in order to realise fully the opinions which prevailed when he first entered the arena. But we will only refer to the views of Hutton, which most nearly approach those of Sir Charles Lyell, who points out that "the characteristic feature of the Huttonian theory was the exclusion of all causes not supposed to belong to the present order of nature. . . . But Hutton had made no step beyond Hooke, Moro, and Raspe, in pointing out in what manner the laws now governing subterranean movements might bring about geological changes if suffcient time be allowed. He therefore required alternate periods of general disturbance and repose; and such he believed had been and would for ever be the course of nature" (Ist ed. p. 63, r ith ed. p. 76).

The views which Hutton and his eloquent illustrator

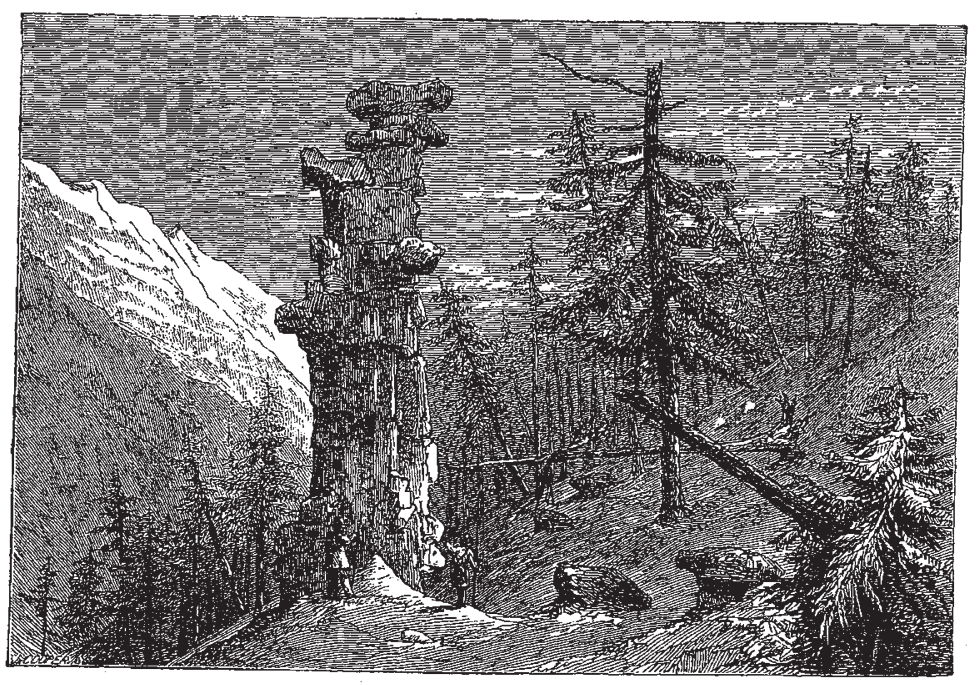

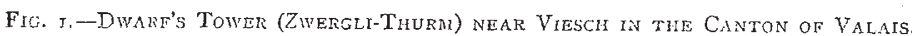
(Fron a Sketch by Lady Lyell, taken Siftember 1857.)

Playfair taught were far from meeting with general reception, and Lyell had to combat the catastrophic views of their opponents, and also to carry Hutton's uniformitarian principle further than Hutton himself allowed, and show by an appeal to observations in regions which are and have recently been in a state of volcanic activity that local catastrophic action is not inconsistent with continuity of causation. "There can be no doubt," says Sir Charles, "that periods of disturbance and repose have followed each other in succession in every region of the globe, but it may be equally true that the energy of subterranean movements has been always uniform as regards the whole earth. The force of earthquakes may for a cycle of years have been invariably confined as it is now, to large but determinate spaces, and may then have gradually shifted its position, so that another region which had for ages been at rest became in its turn the great theatre of action" (Ist ed. p. 64, rith ed. p. 77).

Our author places before us a vast array of facts collected by himself and others all over the world, which

* "The Principles of Geology, or the Modern Changes of the Earth and its Inhabitants considered as illustrations of Geology." By Sir Charles Lyell, Bart. $x$ xth and entirely revised edition. (London: J. Murray, $x^{8} 8_{2}$.) show the ceascless waste going on by rain, rivers, sea, frost, and ice.

The hills are shadows, and they flow

From form to form, and nothing stands.

He explains how all the land must in time be carried away and one vast ocean roll all round the world were there no compensating forces. But then he points out to us that nature does provide a compensating action in the accumulation of volcanic ash and lava thrown out during eruptions, in the upheaval of large tracts of land from below the sea, and still further, that it is part of nature's plan to shift the scene of action.

We will select a few examples from the facts addured in proof of the gradual waste of the land.

Speaking of the effect produced by rain, our author says:- "It is not often that the effects of the denuding action of rain can be studied separately or as distinct from those of running water. There are, however, several cases in the Alps... where columns of indurated mud varying in height from $20 \mathrm{ft}$. to $100 \mathrm{ft}$, and usually capped by a single stone, have been separated by rain from the terrace of which they once formed a part, and 
now stand at various levels on the steep slopes bounding narrow valleys" (p. 329). "This mud, which is very hard and solid when dry, becomes traversed by vertical cracks after having been moistened by rain, and then dried by the sun. Those portions of the surface which are protected from the direct downward action of the rain by a stone or erratic block, become gradually detached and isolated." "The lower part of some of these ancient columns . . . has acquired new capping stones by the wearing out at the surface of blocks originally buried at great depths" (p. 332).

There they stand, a measure of the mass of drift that has been carried away by rain, as workmen sometimes leave a pillar of brickearth or clay here and there over a field to measure the depth of the earth they have removed.

They remind us also of the small pedestals of limestone which large boulders have sometimes preserved for themselves in the same way, and of the ice pillars where the thick stone cap had to keep off the sun instead of the rain.

By the courtesy of the publisher we are able to subjoin a sketch given by our author of an isolated stone-capped column seen by him near Viesch (Fig. I).

In considering the action of rivers, Sir Charles notices how the clearing of forests increases the erosive power of the rain water. Speaking of a ravine in Georgia, he says, "before the land was cleared it had no existence, but when the trees of the forest were cut down, cracks three feet deep were caused by the sun's heat in the clay, and during the rains a sudden rush of water through the principal crack deepened it at its lower extremity, from whence the excavating power worked backwards till, in the course of twenty years, a chasm measuring no less than $55 \mathrm{ft}$. in depth, 300 yards in length, and varying in width from $20 \mathrm{ft}$. to I 8 oft., was the result" (p. 339).

In many parts of France the destruction of the woods has proved a source of very great injury, as they caught the rain and parted with it slowly, the roots all the while protecting the soil. But, now that the woods have been cut down, the water runs off at once, scouring away the earth from the slopes of the hills, and in the valleys causing sudden floods which sweep everything before them.

In America it is especially interesting to watch the effect produced by man in this way upon climate an 1 water supply.

We are shown the power of rivers, especially in flood, to tear away and transport to long distances the broken masses they find in their path. The glacier and icesheet, too, are for ever grinding and wearing the solid rocks away. But space will not allow us to give more than one other example, and we will select the formation

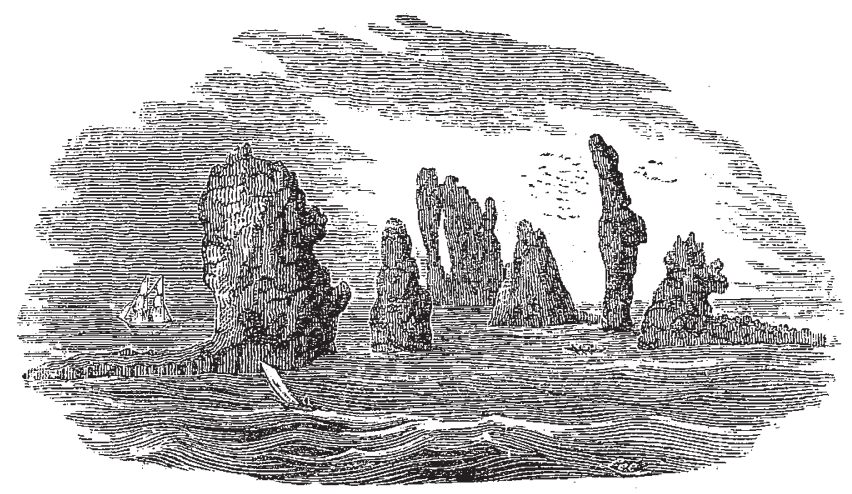

Fig. 2. -Granite Rocks to the South of Hillswick Ness, Shetland.

of a pinnacle of solid rock by the action of the sea, which it will be interesting to compare with the column of indurated mud, of which we have given a sketch above.

In considering the waste of sea cliffs, our author quotes Dr. Hibbert's account of a passage forced by the waves through rocks of hard porphyry, where the sea tears large masses of stone from the sides and forces them along, sometimes to a distance of no less than $180 \mathrm{ft}$, and adds: - "Such devastation cannot be incessantly committed for thousands of years without dividing islands, until they become at last mere clusters of rocks, the last shreds of masses once continuous. To this state many appear to have been reduced, and innumerable fantastic forms are assumed by rocks adjoining these islands, to which the name of Drongs is applied, as it is to those of similar shape in "Feroe"' (p. 512). (Fig. 2.)

By such illustrations we are taught how ceaseless and how powerful are the destroying agencies of nature. But where is all this matter transported to? Sir Charles Lyell takes us out into mid-ocean, where he points out to us the icebergs carrying their load far and wide, and dropping it here and there over the sea bottom in warmer climes. On the shingle beach we see it travelling, and in the deep blue sea, says Dr. Tyndall, we see finelydivided matter still travelling on. With our author we examine the deltas of the great rivers, the Nile, the Ganges, and the Mississippi ; and he shows us that some of the material is for a time arrested there. He tells us of the most recent discoveries in mid-Atlantic, where a chalky mud is being deposited over an area wider than that over which the ancient chalk sea has been traced; where swarms of little creatures live and die, and drop their tiny shells in such countless millions that the mud is in a great measure made up of them; where they Sow

The dust of continents to be,

and give to us the explanation of the conditions under which that great deposit known as the Chalk was formel. Sir Charles Lyell refers to this in the following passage: "A fallacy which has helped to perpetuate the doctrine that the operations of water were on a different and grander scale in ancient times, is founded on the indefinite areas over which homogeneous deposits were supposed to extend. No modern sedimentary strata, it was said, equally identical in mineral character and fossil contents, can be traced continuously from one quarter of the globe to another. But the first propagators of these opinions were very slightly acquainted with the inconstancy in mineral composition of the ancient formations, and equally so of the wide spaces over which the same kind of sediment is now actually distributed by rivers and currents in the course of centuries. The persistency of character in the older series was exaggerated ; its extreme variability in the newer was assumed without proof. In 
the chapter which treats of river deltas and the dispersion of sediment by currents, and in the description of reefs of coral now growing over areas many hundred miles in length, I shall have opportunities of convincing the reader of the danger of hasty generalisations on this head. I may also mention in this place that the vast distance to which the White Chalk can be traced east and west over Europe as well as north and south, from Denmark to the Crimea; seemed to some geologists a phenomenon to which the working of the causes now in action present no parallel. But the soundings made in the Atlantic for the submarine telegraph have taught us that white mud formed of organic bodies similar to those of the ancient Chalk, is in progress over spaces still more vast" (p. I09).

The teaching of Sir Charles, Lyell is that all the rocks have been formed from pre-existing rocks as far back as we can trace them, in the same manner as they are being formed now, and that those which we see preserved are such as from their nature or surrounding circumstances were fittest to survive the various denuding forces to which they would from age to age be subjected.

Surely this is the true theory of evolution applied to geology. It does not, on the one hand, hold that the world has been going on always just as it is-that after a long period, during which all the varied forces of nature have been in full activity, the earth could be found in the same state as it was at the commencement. Nor, on the other hand, does it teach that the earth has been developed according to any original tendency or impulse, but that by the uniform action of forces such as we see now in operation it has been evolved out of previous states.

Nor is the objection valid that there is any "weakness or logical defect" in the teaching which would limit the inquiry to the period of which we have a record in the crust of the earth. If the true methods are employed; it is no objection to the methods themselves that their application is not more extended.

What were the possible or necessary first combinations out of a chaotic mass is a fair subject for investigation; but an author is no more to be censured for excluding it from a work treating of the visible crust of the earth, than a philosophic writer on the history of England is to be blamed for not including in his inquiry the conditions of that part of the earth now represented by our island previous to its last emergence from below the sea,

\section{T. MCK. HUGHES}

(To be continued.)

\section{NOTES}

Prof. Huxley's friends will be rejoiced to hear that he has returned to this country, with his health and strength fully recruited by his absence from work; and that he has already resumed his lectures at the Government School of Mines.

THE Examiner prints the following extract of a letter from M. Elisée Reclus, dated Zurich, March 18 :- "I am able at last to tell you that I am free. After having been kept for a long time in prisons, and sent from one prison to another, I.left Paris for Pontarlier, escorted by two police agents, who left me on the free soil of Switzerland. While breathing and enjoying thepure air of liberty, I do not forget those to whom I am indebted for my freedom. Having been claimed by so many Englishmen as a student of science, I shall work on more than ever to show them my gratitude by my works and deeds."

THE Astronomer Royal will hold his first reception, as President of the Royal Society, on Saturday evening, the 27th inst.

IT will be seen from our report of the Proceedings of the Chemical Society that Prof. Cannizzaro has been selected by the Council to deliver the Faraday lecture on Thursday, May 30.
THE Council of the Society of Arts has invited members of the Society to forward to the secretary, on or before April 29, the names of such men of high distinction as they may think worthy of receiving the Albert Medal, instituted to reward "distinguished merit in promoting arts, manufactures, or commerce." The recipients of the medal since its foundation, in 1864 , have been Sir Rowland Hill, K.C.B., the Emperor of the French, Prof. Faraday, Sir W. Fothergill Cooke and Sir C. Wheatstone, Sir Joseph Whitworth, Baron von Liebig, M. de Lesseps, and Mr. Henry Cole, C.B.

Mr. H. E. ARMStrong has been appointed Lecturer on Botany and Vegetable Physiology at the University of Durham College of Medicine, Newcastle-upon-Tyne.

A NUMBER of gentlemen connected with the Iron and Steel Institute, from the different parts of the Kingdom, and also from the Continent, assembled last week to the number of 200 or 300 at the Teeside Works, Middlesborough, belonging to Messrs. Hopkins, Gilkes, and Co., to witness the first public trial of the rotary puddling machine of Mr. Danks, to which we have recently referred. The machine has been in work for two or three weeks, and realises all that has been claimed for it by its inventor, and all that has been stated of its practicability by the Iron and Steel Institute Commission, which was sent to the United States to investigate the working of the machine. On Friday the gentlemen present saw the machine charged two or three times with molten metal, and generally the heat took about an hour, with all the different preparations, from the time of drawing the heat till the introduction of another. The quantity puddled at one time was between 5 and $6 \mathrm{cwt}$. generally, but as high as I, ooolbs. have been put into the furnace at one charge. The iron, after leaving the furnace, was hammered, and then re-heated and rolled into bars, the quality of which was stated to be very superior. They were all produced from No. 4, Cleveland pig iron. The "fettling" consisted of American ore and pot. tery mine. The important adjunct of a "seezer," which is part of Mr. Danks's invention, is not yet built, so that the operation was not complete. An tunexpected occurrence happened later in the day, an opinion having been received from counsel that Mr. Danks's patent was not valid. A meeting was held between Mr. Danks and most of the gentlemen who had entered into the provisional arrangement to pay him by the roth of April $50,000 \%$. for the right of 200 of his furnaces, to which we have already alluded, and he was informed that the arrangement would not be ratified. The question remains open, and is entrusted to a committee of the gentlemen interested, who will report to a future meeting.

THE establishment is announced of a Meteorological Observatory at the top of the mountain of Puy-de-Dôme. The original cost of $r, 000$ fr. will be borne one-half by the State, one-fourth by the town of Clermont, and one-fourth by the Council-General of Puy-de-Dôme. The annual cost of its maintenarice will devolve on the town of Clermont.

Captain H.R.H. the Duke of Edinburgh, K.G., has signified his intention of becoming a vice-president of the Institution of Naval Architects.

UNDER the new management and direction of the Rogal Polytechnic Institution, it has been determined to re-establish the scientific department of the Institution, and Mr. Edward V. Gardner has been appointed Professor of Chemistry. We understand that the Institution is about to arrange a wellorganised laboratory, proper chemical accessories for lectures, classes, analyses, \&c., of which due notice will be given in the papers when the arrangements are completed

THE Council of the Literary and Philosophical Society of Leicester have received from Mr. John Bennett the sum of 2ogs., 